\title{
Cytogenetic analysis of mouse oocytes after experimental induction of follicular overripening*
}

\author{
Susan C. Laing, R. G. Gosden and H. M. Fraser $\dagger$ \\ Department of Physiology, University Medical School, Teviot Place, Edinburgh EH8 9AG and \\ $\dagger$ †.R.C. Reproductive Biology Unit, 37 Chalmers Street, Edinburgh EH3 9EW, U.K.
}

\begin{abstract}
Summary. Graafian follicle overripening was induced in (1) adult mice by inhibiting the ovulatory discharge of gonadotrophins with antibodies to LH-RH and (2) immature mice by injection of PMSG to promote follicular maturation before the neuroendocrine system was competent to produce an ovulatory stimulus. The numbers of follicles capable of meiotic maturation after exogenous LH were sharply reduced during the period of overripening and there was a corresponding increase in the proportion of cystically enlarged follicles, many of which were undergoing atresia. Freshly ovulated ova were collected after delaying ovulation for 2 days and prepared for cytogenetic study of metaphase chromosomes. The incidence of non-disjunction and other errors was indistinguishable from that of ova collected after spontaneous ovulation during 4or 5-day cycles.
\end{abstract}

\section{Introduction}

Responsibility for early developmental errors has been attributed partly to delayed ovulation ('overripening') of Graafian follicles. Evidence in support of this postulated mechanism has been obtained from studies of Xenopus laevis (Witschi \& Laguens, 1963), rats (Butcher, 1975; Mikamo \& Hamaguchi, 1975) and rabbits (Bomsel-Helmreich, 1972) but there have been no comparable studies of the mouse, despite the fact that this is a preferred species for mammalian cytogenetics.

Two new experimental models have been developed for studying the effects of follicular overripening in mice: (1) inhibition of the ovulatory surge of gonadotrophins by antibodies to luteinizing hormone-releasing hormone (LH-RH), and (2) Graafian follicle development was promoted by PMSG in immature mice that were incapable of producing an endogenous stimulus for ovulation. In both methods ovulation could be induced with exogenous luteinizing hormone (LH) after a pre-determined period of overripening. Oocytes obtained in this way were analysed for errors of chromosome segregation during the first meiotic division.

\section{Materials and Methods}

Female CBA/Ca mice were obtained from the inbred colony of the Department of Physiology, University of Edinburgh, where they were maintained on a lighting schedule of $14 \mathrm{~h} \mathrm{light}$ (lights on at $05: 00 \mathrm{~h}$ ) per $24 \mathrm{~h}$ and at $20-22^{\circ} \mathrm{C}$. A pelleted diet and water were always available.

* Reprint requests to Dr R. G. Gosden. 


\section{Induction of follicular overripening}

Adult mice. Virgin animals aged 3-6 months were removed from stock cages and housed singly so that a daily history could be compiled of vaginal smears taken by lavage. Smears were obtained at 10:00-12:00 $\mathrm{h}$ and were examined unstained by phase-contrast microscopy. Animals were used when they had exhibited at least two consecutive 4- or 5-day oestrous cycles. They were injected with $0.2 \mathrm{ml}$ LH-RH antiserum obtained from a ewe (No. 27) that had been immunized with synthetic LH-RH conjugated to BSA by carbodiimide (Clarke, Fraser \& McNeilly, 1978). The antiserum was directed towards the C-terminal end of the LH-RH molecule and showed no significant cross-reactivity $(<0.01 \%)$ with thyrotrophin-releasing hormone, somatostatin, oxytocin or $\mathrm{LH}-\mathrm{RH}_{1-10}-\mathrm{OH}$, but did show cross-reaction with $\mathrm{LH}-\mathrm{RH}_{2-10}(3 \%)$ and $\mathrm{LH}-\mathrm{RH}_{3-10}$. Each mouse received an injection i.p. at $12: 00 \mathrm{~h}$ on the day before ovulation was expected, i.e. on the day of pro-oestrus in 4-day and of oestrus I in 5-day cycles. Control animals were injected with $0.2 \mathrm{ml}$ saline $(9 \mathrm{~g} \mathrm{NaCl} / 1)$. Those treated with antiserum were induced to ovulate by injection of 2.5 or $7.5 \mu \mathrm{g}$ ovine LH (oLH-22/23, kindly donated by Dr S. Raiti through the NIAMDD, Bethesda, MD, U.S.A.) at 06:00 or 18:00 h on the first or second day after pro-oestrus. The animals were killed by asphyxia in 100\% nitrogen at 10:00-12:00 h on the morning of ovulation for collection of oviducal ova or $6 \mathrm{~h}$ after injection of LH for ovarian histology. Blood was collected from the heart immediately post mortem and prepared as serum for assaying the titre of LH-RH antibodies by the method of Clarke et al. (1978).

Immature mice. Animals aged 20 days and weighing $6.95-8.05 \mathrm{~g}$ received an injection i.p. at 18:00 h of 5 i.u. PMSG (100 i.u./ml; Organon, Oss, The Netherlands, courtesy of Dr B. M. Hobson). Pilot experiments showed that animals outside this weight range either failed to respond to gonadotrophin or ovulated spontaneously after treatment. Ovulation was induced in immature mice in a way similar to that used for the adult animals by injection i.p. of $\mathrm{LH}$ at 48,60, 72, 84 or $96 \mathrm{~h}$ after PMSG. Animals were killed on the morning of ovulation or $6 \mathrm{~h}$ after injecting LH.

\section{Recovery and preparation of oocytes}

Freshly ovulated ova were liberated from the swollen oviducts into Medium 199 (Flow Laboratories, Irvine, U.K.) containing 1\% BSA (B.D.H., Poole, U.K.) and $100 \mathrm{U}$ ovine hyaluronidase/ml (Sigma, London, U.K.). After dispersal of the cumulus cells, the oocytes were counted and transferred to $0.85 \%$ sodium citrate solution for $15 \mathrm{~min}$ and then to clean glass slides for fixation by the method of Tarkowski (1966). Air-dried slides were stained for centromeric heterochromatin (Chandley \& Fletcher, 1973) and mounted. The numbers of metaphase chromosomes and prematurely disjoined chromatids of the oocytes were counted using oilimmersion optics $(\times 1000)$. Metaphase preparations with substantially overlapping or widely dispersed chromosomes were ignored. A similar percentage of successful preparations was made of each experimental group and overall this was $41 \%$.

\section{Histology of ovaries}

Ovaries were removed at autopsy, fixed in aqueous Bouin's fluid and prepared as serial paraffin-wax sections of $7 \mu \mathrm{m}$ thickness stained with haematoxylin and eosin. Slides were coded and the total numbers of antral follicles were counted for each animal. Large Graafian follicles were classified according to their size and morphology: those of normal preovulatory appearance were VIb and 'cystic' types with an enlarged antrum were VIc (Gosden, Laing, Felicio, Nelson \& Finch, 1983). The numbers of pycnotic granulosa cells were counted in one approximately equatorial section passing through the nucleolus to provide an indication of atresia. Finally, the sizes of some of the follicles and their oocytes were measured with an ocular micrometer and their morphological appearance was recorded. 


\section{Results}

\section{Experimental production of follicular overripening}

Adult mice. A single injection of anti-LH-RH serum given shortly before the expected time of the preovulatory discharge of gonadotrophins inhibited ovulation in all 17 mice (Table 1) whereas 82 of 89 individuals amongst several cohorts of control animals had ovulated on the projected day of oestrus in 4- and 5-day cycles. By the 2 nd day after injection, 1 animal had ovulated $(2.9 \%)$ and the incidence of ovulation continued to rise thereafter until, on Day 14, all mice had ova in the oviducts. During the period of ovulation inhibition, the oestrous cycles were suppressed and replaced by persistent vaginal cornification although some leucocytes were usually present. The antibody titres were low even on the first day after injection (median $1: 100$ ) but were undetectable by Day 7 $(<1: 50)$.

Table 1. Short-term inhibition of ovulation in 4- and 5-day cyclic mice after injection of $0 \cdot 2 \mathrm{ml}$ ovine antiserum to LH-RH at $12: 00 \mathrm{~h}$ on the day of pro-oestrus

\begin{tabular}{ccc}
\hline \multirow{2}{*}{$\begin{array}{c}\text { Interval between } \\
\text { treatment and }\end{array}$} & \multicolumn{2}{c}{$\begin{array}{c}\text { No. of animals with oviducal } \\
\text { ova/total no. animals }\end{array}$} \\
\cline { 2 - 3 } autopsy (days) & 4-day cycle & 5-day cycle \\
\hline 1 & $0 / 8$ & $0 / 9$ \\
2 & $0 / 9$ & $1 / 9$ \\
3 & $1 / 9$ & $1 / 8$ \\
7 & $2 / 5$ & $0 / 5$ \\
14 & $5 / 5$ & $5 / 5$ \\
\hline
\end{tabular}

The numbers and appearance of large antral follicles were studied during the first 3 days after treatment with antiserum following a 4-day cycle. During this period the size of the VIb population remained approximately constant whereas the numbers of cystic VIc type follicles increased substantially over the same period ( $P<0.05$ by Newman-Keul's studentized range test). The latter types were characterized by an enlarged antrum and a granulosa cell population which was exceptionally polarized towards the region of the oocyte with a mural population only 1 or 2 cell layers thick (Pl. 1, Fig. 1). The proportion of VIb follicles that were atretic increased on the days after treatment $(P<0.05)$ and that of VIc follicles remained close to $100 \%$ atresia.

Some animals were given an injection of $\mathrm{LH}$ to identify the follicles that were sensitive to ovulatory stimuli after delay of ovulation. Breakdown of the germinal vesicle (GVB) of the oocyte and mucification of the neighbouring cumulus cells in VIb and VIc follicles $6 \mathrm{~h}$ after injection were adopted as criteria for sensitivity. Untreated ovaries never presented follicles with this appearance except at advanced stages of atresia. The numbers of follicles with this appearance declined substantially with increasing time between injections of antiserum and $\mathrm{LH}$ and there was a concomitant increase in the proportion of type VIc follicles containing few pycnotic cells $(<10$ per section) (Text-fig. 1a). However, not all of the follicles responding would have proceeded to ovulation since fewer ova were collected from the oviducts of a comparable group of animals that were killed after ovulation (Text-fig. 1a). A comparison of these data also shows that a substantial proportion of ovulated ova came from follicles classified as VIc.

The proportion of animals ovulating and the numbers of ova shed per animal by 5-day cyclic animals 2 days after antiserum treatment were less than half of the values of comparable animals with 4 -day cycles $(P<0.005)$. Since very few ova could be obtained from the former group the cytogenetic data presented below are based upon treatment of 4-day cyclic mice only and the results in Text-fig. 1(a) were obtained from this type of animal. 

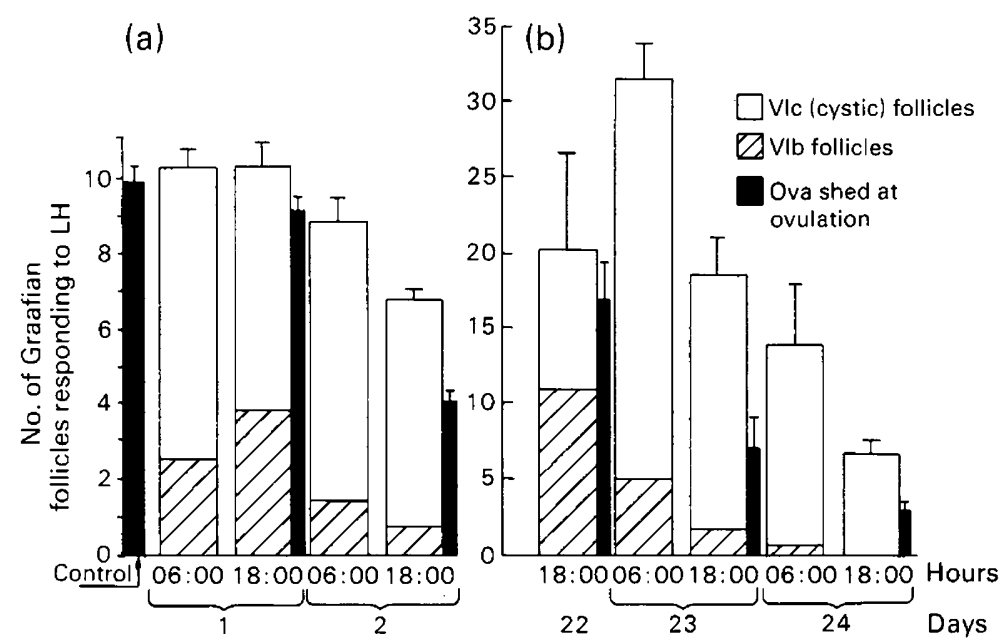

Text-fig. 1. Total numbers of Graafian follicles at stages VIb and VIc in mouse ovaries that responded to exogenous $\mathrm{LH}$ by breakdown of the germinal vesicle and mucification of cumulus cells at various intervals after (a) inhibition of ovulation with anti-LH-RH serum in 4-day cyclic adult mice, and (b) administration of PMSG to immature mice. The numbers of ova shed at ovulation in animals receiving similar treatment are shown for comparison.

Immature mice. Spontaneous ovulation did not occur during the week after PMSG treatment of 20 -day-old mice. Injection of LH on Day 22 produced an ovulatory response in $94 \%$ of animals, although when injection was delayed until 18:00 h on Day 24 significantly fewer ova were shed per animal $(P<0.025)$.

The numbers of VIb follicles were very low on the day of PMSG treatment $(<2$ /animal) but were increased at least 5 -fold on the 4 subsequent days. Follicles of type VIc were present from Day 22 and they increased in number on the 2 subsequent days. The proportions of atretic follicles with $\geq 2$ pycnotic cells / section at both of these stages increased from Day 22, and by Day 24 most antral follicles contained $>10$ pycnotic cells.

The number of large Graafian follicles responding to LH treatment are shown in Text-fig. 1(b). The rate of decline in numbers of responsive follicles in immature mice was greater than that of adult mice and was approximately exponential from the morning of Day 23 with a population half time of $15 \mathrm{~h}$. Fewer ova were shed from the ovaries of immature and adult mice than was suggested by the numbers of follicles showing GVB, and both types of animal contained an increasing proportion of VIc follicles with increasing time after PMSG or pro-oestrus, respectively.

\section{Cytogenetic analysis of oocytes}

The majority of oocytes in adult and immature mice were haploid (Table 2; Pl. 1, Fig. 2). Only 3 oocytes $(0.58 \%$ of total) contained 21 chromosomes (Pl. 1, Fig. 3), these being found in an animal with a 5-day cycle and in one animal of both sub-groups in which ovulation had been delayed experimentally for 2 days. Only 19 chromosomes were present in 30 oocytes $(5.8 \%)$. The preponderance of such oocytes amongst control animals was not statistically significant and, furthermore, it was impossible to determine what proportion of them resulted from loss of a chromosome during preparation. Three oocytes $(0.58 \%)$ from 4-day controls contained an unpaired chromatid in addition to the normal set of 20 chromosomes. No diploid oocytes were found. Although these experiments were not strictly designed to test whether PMSG treatment increases cytogenetic anomalies, the results obtained here provided no support of this hypothesis. 


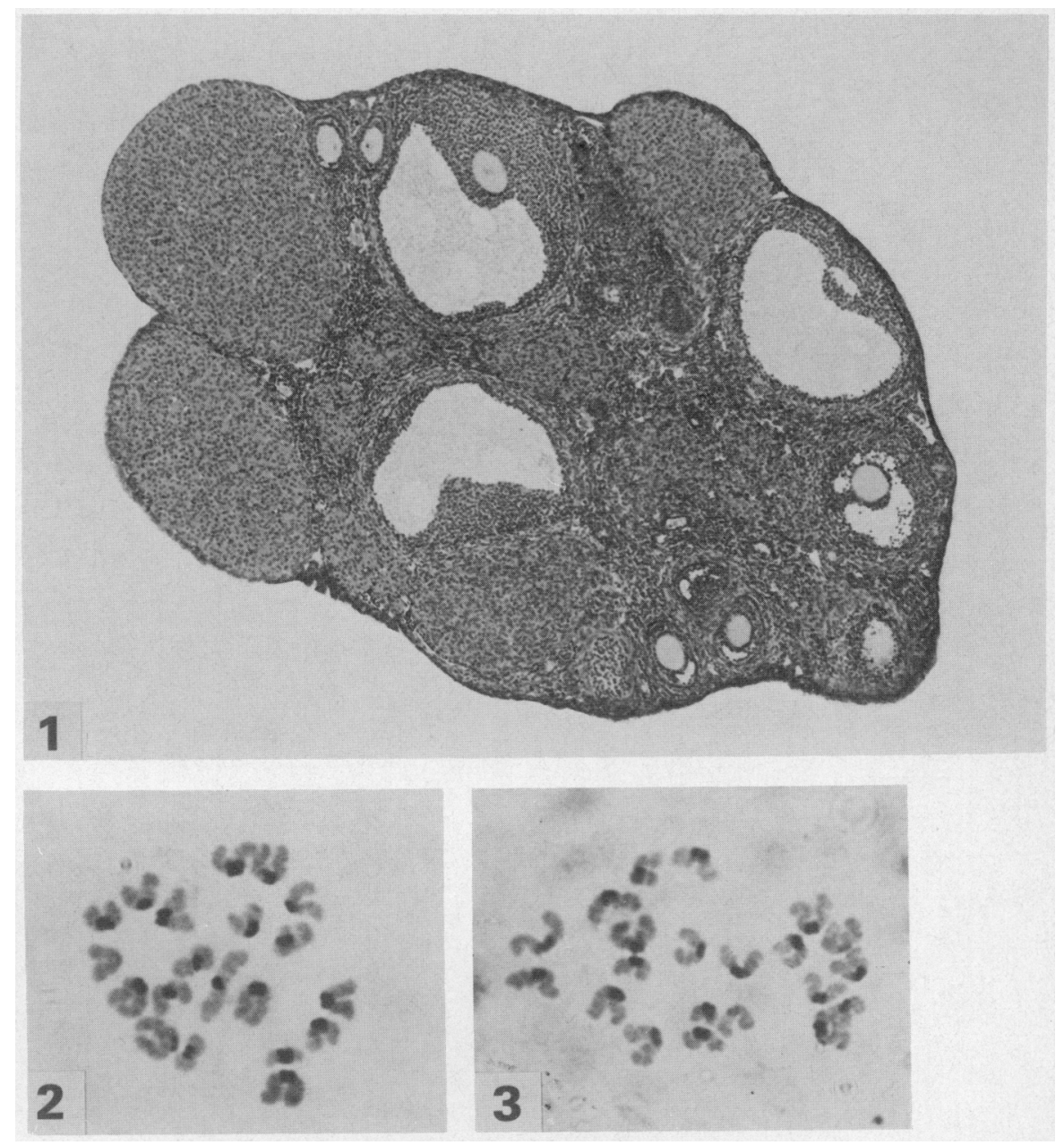

Fig. 1. Ovary of a young adult $\mathrm{CBA} / \mathrm{Ca}$ mouse 2 days after ovulation was inhibited by injection of anti-LH-RH serum on the day of pro-oestrus. The 3 large ('cystic') Graafian follicles have enlarged antra and exceptionally polarized development of granulosa cells. Haematoxylin \& eosin, $\times 50$.

Fig. 2. Metaphase II preparation of a mouse oocyte with a normal haploid complement $(n=$ 20). Giemsa, $\times 1250$.

Fig. 3. Metaphase II preparation of a mouse oocyte with 21 chromosomes $(n+1)$. Giemsa, $\times$ 1250 . 
Table 2. Cytogenetic analysis of mouse oocytes obtained after experimentally delaying ovulation by 2 days (follicular overripening) compared with those ovulated spontaneously (in adult mice) or at the anticipated time of optimal follicular maturity (in immature mice)

\begin{tabular}{|c|c|c|c|c|c|c|c|}
\hline \multirow[b]{2}{*}{ Age group } & \multirow{2}{*}{$\begin{array}{l}\text { Ovarian cycle } \\
\text { length (days) }\end{array}$} & \multirow{2}{*}{$\begin{array}{l}\text { Treatment } \\
\text { group }\end{array}$} & \multirow{2}{*}{$\begin{array}{l}\text { No. of } \\
\text { animals }\end{array}$} & \multirow{2}{*}{$\begin{array}{l}\text { No. of } \\
\text { oocytes } \\
\text { analysed }\end{array}$} & \multicolumn{3}{|c|}{$\begin{array}{l}\text { Distribution of oocytes } \\
\text { according to the number } \\
\text { of chromosomes }\end{array}$} \\
\hline & & & & & 19 & 20 & 21 \\
\hline \multirow[t]{3}{*}{ Adult } & 4 & Control & 29 & 95 & 8 & $87^{*}$ & - \\
\hline & 5 & Control & 38 & 134 & 8 & 125 & 1 \\
\hline & 6 & $\begin{array}{l}\text { Delayed } \\
\text { ovulation }\end{array}$ & 58 & 105 & 2 & 102 & 1 \\
\hline \multirow[t]{2}{*}{ Immature } & - & Control & 17 & 104 & 9 & 95 & - \\
\hline & - & $\begin{array}{l}\text { Delayed } \\
\text { ovulation }\end{array}$ & 66 & 76 & 3 & 72 & 1 \\
\hline
\end{tabular}

* Three oocytes in this group had an additional chromatid.

\section{Discussion}

Two substantially different methods of delaying ovulation were developed for mice and they produced essentially similar results, indicating that Graafian follicles remain capable of ovulation for only a few days after becoming mature and that the probability of non-disjunction of meiotic chromosomes is not significantly increased during the period of overripening as follicles become progressively atretic. It is not known whether oocytes in follicles at more advanced stages of atresia are more vulnerable to segregational errors, but even so this would be of little biological consequence since they are unlikely to remain ovulable.

For technical reasons it was not possible to demonstrate directly by follicle marking that overripening had occurred but this assumption can be drawn from several indirect quantitative and morphological observations, some of which have been presented here. For example, there was no evidence of discrete waves of atresia of large follicles or of replacement by smaller antral stages during the period of study. Profiles of follicle stages present whilst ovulation was delayed suggested that the distributions were continuous, with progressive development of follicles towards the cystic stage (VIc) and, therefore, termination in atresia. This pattern of development may explain the rapid fall in numbers of follicles which were partly or fully responsive to LH. The period of overripening was measured from the day of pro-oestrus in cyclic mice and a maximum period of 2 days of ovulation blockade was chosen since few follicles will respond to treatment on the 3rd day. The timing of overripening in PMSG-primed mice was inevitably arbitrary and was based upon the assumption that follicles were optimally mature 2 days after injection of PMSG (Fowler \& Edwards, 1957); this assumption is consistent with the declining follicular response to later injections.

The method of inducing follicular overripening in immature mice resembles that used in rabbits (Bomsel-Helmreich, 1972) and rats (Peluso, Steger \& Hafez, 1977), but the use of antibodies to LHRH for inhibiting ovulation in mice has not been described previously. The action of the antiserum presumably involves immunoneutralization of LH-RH in hypophysial portal vessels. Direct action on the ovaries is unlikely since LH-RH receptors or endogenous ligands are absent in mice (R. M. Popkin, unpublished observations), although not in rats (Clayton, Harwood \& Catt, 1979). The use of an antiserum has an advantage over the conventional method of pentobarbitone-blockade of ovulation since it does not require precise knowledge of the timing of the critical period for the 
neurogenic stimulus for LH-RH release, whilst the effects on circulating gonadotrophin levels are similar in these methods: namely, abolition of the preovulatory surges with minor reductions of baseline levels (Hasegawa, Miyamoto, Yazaki \& Igarashi, 1981). A further advantage of the 2 models used here is that direct effects of treatment on the meiotic spindle are unlikely, whereas anaesthetic agents may have such effects (Kaufman, 1977).

The consequences of follicular overripening on the quality of oocytes are only of major interest if they develop during the short span of time whilst follicles remain ovulable. It has been proposed that preovulatory deterioration of the oocyte was responsible for the increased incidence of chromosomal anomalies in rat embryos when ovarian cycles were extended to 6 days either spontaneously during ageing or after pentobarbitone treatment (Butcher, 1975; Mikamo \& Hamaguchi, 1975). However, these data do not provide an acceptable statistical basis for showing an effect of follicular overripening on the incidence of trisomy $(P>0 \cdot 20$, by Fisher's exact test), which is consistent with the conclusions obtained here from mice. Follicular overripening probably cannot, therefore, explain the striking effect of maternal age on trisomy arising from nondisjunction at anaphase I (Bond \& Chandley, 1983), although there may be other effects of overripening on oocytes, perhaps involving cytoplasmic structures and membranes, and they may be partly responsible for loss of fertility (Page, Kirkpatrick-Keller \& Butcher, 1983). It remains possible that there is a very low risk of chromosomal non-disjunction as evidenced by the presence of one egg with 21 chromosomes in each of the treatment groups, but there was a similar incidence in animals with normal 5-day cycles. It has been suggested on the basis of the poor ovulatory response and early fall in circulating oestradiol levels during delayed ovulation that preovulatory follicles in 5-day cycles undergo earlier atresia and are at a more advanced stage of development than those in 4-day cycles (van der Schoot, 1980; Laing, 1982), but this hypothesis requires further study.

A few oocytes were found to have an additional chromatid which could not be explained simply as a technical artefact, but it is not clear whether this is a potential basis for trisomy. Whatever is the significance of premature segregration of chromatids, the anomaly does not seem to arise as a consequence of follicular overripening.

We gratefully acknowledge a Fullerton Research Scholarship from the Faculty of Medicine to S.C.L. and an M.R.C. Project Grant to R.G.G.

\section{References}

Bomsel-Helmreich, O. (1972) Effets de l'ovulation retardée sur le développment des blastocystes de lapine. Proc. 7th Int. Kongr. Tierische Fortpflanzung, München, Vol. II, p. 1205, Abstr.

Bond, D.J. \& Chandley, A.C. (1983) Aneuploidy. Oxford University Press.

Butcher, R.L. (1975) The role of intrauterine environment and intrafollicular aging of the oocyte on implantation rates and development. In Aging $\mathrm{Ga}$ metes: their Biology and Pathology, pp. 201-218. Ed. R. J. Blandau. S. Karger, Basel.

Chandley, A.C. \& Fletcher, J.M. (1973) Centromere staining at meiosis in man. Humangenetik 18, 247252.

Clarke, I.J., Fraser, H.M. \& McNeilly, A.S. (1978) Active immunization of ewes against luteinizing hormone releasing hormone, and its effects on ovulation and gonadotrophin, prolactin and ovarian steroid secretion. $J$. Endocr. 78, 39-47.
Clayton, R.N., Harwood, J.P. \& Catt, K.J. (1979) Gonadotrophin-releasing hormone analogue binds to luteal cells and inhibits progesterone production. Nature, Lond. 282, 90-92.

Fowler, R.E. \& Edwards, R.G. (1957) Induction of superovulation and pregnancy in mature mice by gonadotrophins. J. Endocr. 15, 374-384.

Gosden, R.G., Laing, S.C., Felicio, L.S., Nelson, J.F. \& Finch, C.E. (1983) Imminent oocyte exhaustion and reduced follicular recruitment marks the transition to acyclicity in aging mice. Biol. Reprod. 28, 255-260.

Hasegawa, Y., Miyamoto, K., Yazaki, C. \& Igarashi, M. (1981) Regulation of the second surge of folliclestimulating hormone; effects of anti-luteinizing hormone-releasing hormone serum and pentobarbital. Endocrinology 109, 130-135.

Kaufman, M.H. (1977) Effect of anaesthetic agents on eggs and embryos. In Development in Mammals, vol. 1, pp. 137-163. Ed. M. H. Johnson. Elsevier/NorthHolland, Amsterdam. 
Laing, S.C. (1982) Ovarian ageing in the mouse. M.Phil. thesis, University of Edinburgh.

Mikamo, K. \& Hamaguchi, H. (1975) Chromosomal disorder caused by preovulatory overripeness of oocytes. In Aging Gametes: their Biology and Pathology, pp. 72-97. Ed. R. J. Blandau. S. Karger, Basel.

Page, R.D., Kirkpatrick-Keller, D. \& Butcher, R.L. (1983) Role of age and length of oestrous cycle in alteration of the oocyte and intrauterine environment in the rat. J. Reprod. Fert. 69, 23-28.

Peluso, J.J., Steger, R.W. \& Hafez, E.S.E. (1977) Sequential changes associated with the degeneration of preovulatory rat follicles. J. Reprod. Fert. 49, 215218.

Tarkowski, A.K. (1966) An air-drying method for chromosome preparations from mouse eggs. Cytogenet. Cell Genet. 5, 394-400.

van der Schoot, P. (1980) Delay of ovulation in rats with sodium pentobarbitone: apparent differences between rats with 4 - or 5 -day reproductive cycles. $J$. Endocr. 86, 451-457.

Witschi, E. \& Laguens, R. (1963) Chromosomal aberrations in embryos from overripe eggs. Devl Biol. 7, 605-616.

Received 18 April 1983 